\title{
University of Auckland
}

\author{
Sean Sturm
}

From Aristotle to crime scene: a forensics of the academic essay

\begin{abstract}
:
Writing in the academy is almost always about making a claim, or 'case', based on evidence, as one does in court: its rhetoric is forensic (L. forensis 'in open court, public', from forum), in Aristotle's sense. Just as forensic rhetoric takes as a given the laws of the polis and is directed at persuading a judge (Aristotle 1991: 80-82), academic writing assumes a set of rules (one must be sincere, demonstrate one's argument using evidence, and obey a certain decorum) and is written to persuade an assessor, namely a teacher or peer. And, since the Harvard 'forensic system' of essay writing in the late 1870s (Russell 2002: 51-63), it has often been taught in the language of forensic rhetoric: in particular, the apocryphal 'rhetorical triangle' of persuasion by ethos, logos and pathos (Booth 1963; Kinneavy 1971) and the informal logic of the enthymeme (Toulmin 1958). At its best, academic writing provides a forum to animate and air ideas. As such, it is amenable to what Eyal Weizman calls forensis: 'a critical practice' that 'interrogate[s] the relation between ... fields and forums' (Weizman 2014: 9; compare Braidotti 2013 on the 'forensic turn'). For Weizman, a field is a 'contested object or site [of investigation]' and a forum is 'the place where the results of an investigation are presented and contested' (Ibid.). Where forensics allows objects like bodies, weapons and scenes to 'speak', forensis can give voice to sites like academic architecture (Sturm and Turner 2011), forms (McLean and Hoskin 1998) or even essays. Here I explore the academic essay as a forensic site, 'an entry-point from which to reconstruct larger processes, events and social relations, conjunctions of actors and practices, structures and technologies' of the academy (Weizman 2014: 18-19). The academic essay is at once a report on research, an argument, a fractal structure, a means of assessment and, as this essay will argue, an exemplar of and exercise in performativity (Sturm 2012).
\end{abstract}

\section{Biographical note:}

Sean Sturm is Deputy Director of the Centre for Learning and Research in Higher Education at the University of Auckland. He moonlights as a teacher of Writing Studies in the Faculty of Arts at the University of Auckland.

Keywords:

Academic essay - Aristotle - Rhetoric - Bourdieu - Weizman - Forensis 
To choose deliberately the form of the essay is to step away from a path of obedient submission to the academic world. - Joeres and Mittman, The Politics of the Essay (1993: 20)

Here I explore the academic essay as a forensic, or public, site. An academic essay is at once a report on research, an argument, a means of assessment, an exercise in performativity, and a performance (Sturm 2012). At its best, it provides a forum to animate and air ideas. At its worst, it is a crime against writing. As such, it is amenable to what architectural theorist Eyal Weizman calls forensis: 'a critical practice' that 'interrogate[s] the relation between ... fields and forums' (Weizman 2014: 9) in urban landscapes, particularly in occupied territories where buildings serve as weapons. For Weizman, a field is a 'contested object or site [of investigation]' and a forum is 'the place where the results of an investigation are presented and contested' (Ibid.). Where conventional forensics allows objects like bodies, weapons and scenes to 'speak', forensis can give voice to academic 'sites' like architecture (Sturm and Turner 2011), forms (McLean and Hoskin 1998) or even essays. ${ }^{1}$ Here I investigate the academic essay as forensic site, as 'an entry-point from which to reconstruct larger processes, events and social relations, conjunctions of actors and practices, structures and technologies' of the academy (Weizman 2014: 18-19). In short, the academic essay embodies the contractual, risk-averse 'academosphere' today - though it can do so much more. But first, let me trace the forensic origin of the academic essay and what it can tell us about how we learn to write academically.

\section{Forensic rhetoric}

My story of academic writing begins - as does many an academic writer's, it would seem to me - with the kind of three-act narrative arc described in Aristotle's Poetics that can be seen everywhere from films to fairytales, such that it seems part of the cultural DNA of all of us (Vogler 2007). 'A whole is that which has a beginning, a middle and an end', he writes (Aristotle 1902: 31; 1450b27). When called upon to write an academic essay (or article or chapter), we typically tend to shape it the same way with an introduction, a body and a conclusion - whatever the discipline and its variations on the form (Lea and Street 1998). To do so feels somehow right, and our teachers, rubrics and writing handbooks concur on the characteristic 'moves' of the academic essay and its kindred forms (Swales 1990). And we soon learn that each of its sections and paragraphs can be shaped likewise, so that the essay becomes something like a Chinese box (I call this the 'academic fractal' [Sturm 2012]). We also learn usually by hard-won experience of markers' marginal comments - that it is a strange sort of narrative that gives away its ending at the beginning (Williams [1981] calls it 'point-first' writing), like Citizen Kane, which begins with its hero's end.

But when it comes to constructing an academic argument, we are understandably less confident: we tend to mimic the kind of for-and-against debate in which we grudgingly took part at school. This strategy is not wrong, as is suggested by the title of Graff and Birkenstein's excellent introduction to academic argument: 'They Say, I Say' (2006). ${ }^{2}$ But I prefer to think of academic argument as about making claims, or 'cases', based 
on evidence, as one does in court. Thus, it has much in common with forensic, or what Aristotle called dicanic ('lawyerly') rhetoric, the rhetoric of the law court and one of the three species of rhetoric he formalises in The Art of Rhetoric. ${ }^{3}$

Table 1. Aristotle’s three species of rhetoric (Hesk 1990; Garver 1994)

\begin{tabular}{|l|l|l|l|l|}
\hline Species of rhetoric & Function & Focus & Aim & End \\
\hline deliberative (symbouleutikon) & political & future & evaluative/active & audience's best interest \\
\hline epideictic (epideiktikon) & ceremonial & present & observational/passive & praise or blame \\
\hline forensic (dikanikon) & judicial & past & evaluative/active & justice \\
\hline
\end{tabular}

The Rhetoric is essentially a manual for lawyers (see Mangum and Mangum 1983), or, rather, for litigants because in the Greek law courts litigants were required to speak for themselves - although they often employed lawyers to write their speeches (Bers 2009). It casts a long shadow on academic writing and explains some of its more 'shady', or rhetorically slippery, aspects that are amenable to the 'critical practice' that is forensis (Weizman 2014: 9).

Firstly, the Rhetoric enjoins us to consider the audience for our academic writing. Forensic argument was to be directed at the judge, in particular, at the 'received wisdom' (endoxa) of the laws of the polis that speak through him, just as academic argument is to be directed at an assessor and the laws of the academy that they police. For this reason, it emphasizes that we must understand psychology to best appeal to our audience and their understanding of psychology. For students of academic writing, that translates to 'give your marker what they want!' because, when challenged, assessors will respond: 'you have to know the rules before you can break them' (I say '... so that you can bend them') - even though those 'rules' are mostly unwritten. It thus encourages a strategic stance toward our reader and an instrumental attitude to our writing.

Secondly, the Rhetoric alerts us to the fact that academic writing is about persuading our audience through more than just formal logic (this is the lesson of that classic on informal argument, Stephen Toulmin's The Uses of Argument [2003]). It describes three pisteis ('modes of persuasion') that contribute to the persuasiveness of an argument:

- the authority of the speaker, or author (ethos, 'disposition', or authority)

- the logical argument set out in the text (logos, 'reason', or argument)

- the emotional effect created by the speaker and text on the audience (pathos, 'passion', or emotion).

This triad is commonly represented as the apocryphal 'rhetorical triangle' (Booth 1963; Kinneavy 1971): 


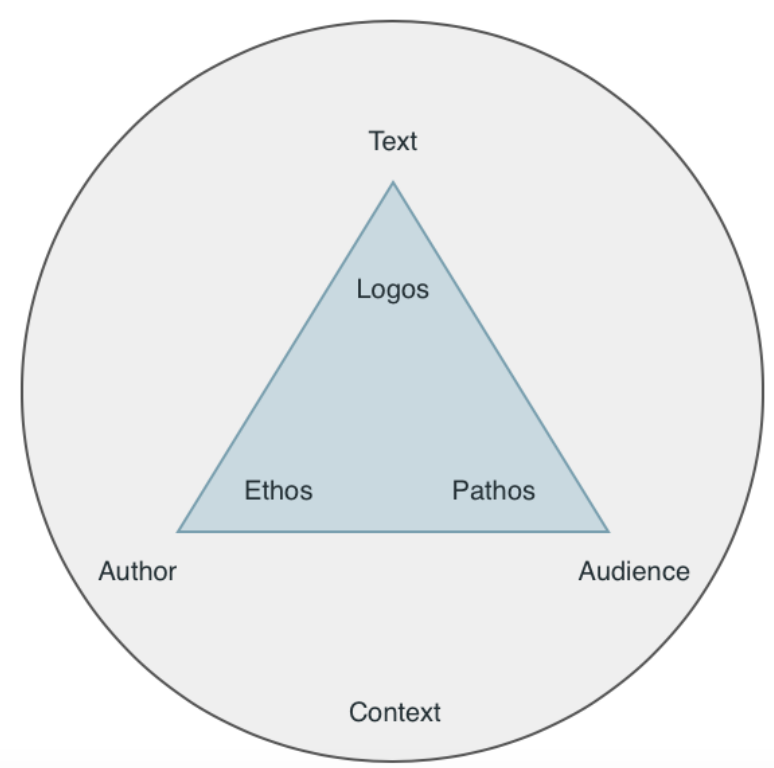

Figure 1. The rhetorical triangle

Only the mode of argument (logos) is 'logical'; the modes of authority and emotion are non-'logical', but vital for lawyers, as every courtroom drama on television attests. They are no less vital for academic writers. We writers must establish our authority to speak (ethos), not only by presenting our argument 'logically' in its structure, claims and evidence, but also by following whatever conventions of tone, register, voice, grammar, orthography, typography and referencing we assume is expected by our assessors. Typically, we infer that for our writing to qualify as 'academic', it should be sincere, formal, generic, hypotactic, in Standard written English, primarily textual, and referenced according to the style of our discipline. (This is not to say that our academic writing can't exhibit non-'academic' stylistic features intentionally or unintentionally [Sturm 2012], nor that non-academic writing doesn't often exhibit 'academic' stylistic features.)

Table 2. 'Academic' and non-'academic' stylistic features

\begin{tabular}{|l|l|l|}
\hline Feature & 'Academic' & Non-'academic' \\
\hline tone & sincere & comic, satirical, parodic, ironic \\
\hline register & formal & informal, mixed \\
\hline voice & generic, authentic & individual, positional \\
\hline grammar & hypotactic (co-/subordinated) & paratactic (juxtaposed), elliptical \\
\hline orthography & $\begin{array}{l}\text { in Standard written English with } \\
\text { technical terminology }\end{array}$ & $\begin{array}{l}\text { in non-standard English: dialectical, } \\
\text { idiolectical, neologistic, 'poetic' }\end{array}$ \\
\hline typography & (mainly) textual & visual, hypertextual \\
\hline referencing & referenced in a disciplinary style & unreferenced, plagiaristic \\
\hline
\end{tabular}


Further, to maintain our authority, we infer that we must present our arguments as if without pathos ('objectively') - unless our discipline is one of those in which a tone of polite indignation is accepted - and as if we believed them ('authentically'). ${ }^{4}$ In effect, we must create an authoritative persona (Latin, 'mask') through which to argue, just as the Greek lawyer had to when they impersonated their client (the Greek term was prosopopoeia, 'personification') (Rorty 1996: xiii). Whatever the rhetorical purpose of the writing, that persona should have the courtroom demeanour of a lawyer: calm, measured - and politely dressed in decorous, or 'classic', prose (Thomas and Turner 2011). In other words, the Rhetoric implies that we should not only be strategic, but also attempt to appear not to be, in order to be persuasive.

Thirdly, the Rhetoric encourages us to see academic arguments as for or against something (as apology [Greek 'defence'] or polemic [Greek 'war']), just as in those debates of childhood or in courtroom dramas. But it also explores more deeply the nature of claims and evidence. It argues that forensic arguments work through demonstration (apodeixis) by causal explanation (aitiain) - which is familiar to us from any number of detective movie denouements in which the sleuth spells out to us by whom and how the crime was committed. Unless the arguments are straightforwardly evidential, or 'non-artistic' (atekhnikos), they are inductive or deductive, or 'artistic' (entekhnikos). Inductive argument relies on paradeigma ('pattern; precedent; example'), or inference from data; deductive argument, on enthymeme ('reasoning'), or derivation from laws. Although Aristotle considers enthymeme the most sophisticated type of argument, we tend to combine all three types - evidence, induction and deduction - in academic writing.

However, something shadier is also going on in forensic deduction - and academic writing generally. Forensic deduction 'adjusted' data to laws, selecting evidence based on what a reasonable person could be expected to infer about what happened and how it happened, that is, on what was 'reasonable', or probable (eikos), not on what was true. $^{5}$ (This is why lay people have tended to be suspicious of lawyers - and should perhaps be more so of academic writing.) Furthermore, its logic typically consisted of syllogisms ('Murderers are punishable by death; So-and-So is a murderer; therefore, So-and-So should be put to death') with the major or minor premise missing or problematic, namely, either the law ('Murderers are punishable by death') or the case ('So-and-So is a murderer').

Table 3. Enthymemes

\begin{tabular}{|l|l|l|}
\hline $\begin{array}{l}\text { Major premise } \\
\text { (law) }\end{array}$ & [law?] & $\begin{array}{l}\text { Murderers are punishable by } \\
\text { death }\end{array}$ \\
\hline $\begin{array}{l}\text { Minor premise } \\
\text { (case) }\end{array}$ & So-and-So is a murderer & [evidence?] \\
\hline Conclusion & $\begin{array}{l}\therefore \text { So-and-So should be put to } \\
\text { death }\end{array}$ & $\begin{array}{l}\text { So-and-So should be put to } \\
\text { death }\end{array}$ \\
\hline
\end{tabular}


In a legal case, both the case and the law of which it is an instance ought to be valid for the argument to be sound - but one of the two is usually elided; in academic writing, the same is often true. ${ }^{6}$ In academic writing, the 'laws' from which we deduce are frequently unwritten. In this essay, I am constructing a forensic 'genealogy' (Foucault 2000a) - a secret history - of the academic essay, a genealogy being an argument for the historical contingency of social phenomena based on the 'law' that the real cause of a phenomenon, its 'condition of possibility', is often hidden. ${ }^{7}$ But this kind of reflexive argumentation isn't common; instead, we tend to cite authorities' arguments as precedents - as I do throughout this essay when I cite Aristotle's arguments about argumentation, for example. In short, the Rhetoric infers that academic writing is often less than 'logical' and relies instead primarily on appeals to emotion or authority (argumenta ad passiones or ad verecundiam) to persuade its audience.

\section{'Forensics'}

While the Rhetoric was outshone by Cicero's (apocryphal) Rhetorica ad Herennium (1968) and De Inventione (1976) in the teaching of rhetoric until at least the Renaissance (Murphy 1974), it comes to light in modern times with the Harvard 'forensic' system that lasted there from the late 1870s to late 1890s, and elsewhere until the 1920s (Russell 2002). Harvard forensics marks the first use of forensic rhetoric to teach not oratory, but academic writing. It was a proto-Writing Across the Curriculum programme devised by Adams Hill, ${ }^{8}$ then Boylston Professor of Rhetoric, that involved 'college-wide writing requirements from entrance to graduation' (Russell 2002: 51). It culminated in a written argument or 'theme' that was 'a written adaptation of oral debate' (Russell 2002: 52), and thus continued the tradition of debate as a capstone activity in the degree, as is the case with the viva voce or disputation still customary in doctorates today (Clark 2008). It was always challenging to implement because the curriculum was, even then, increasingly departmentalised, content-heavy and supplemented with electives, and its writing requirements, discipline-specific. The theme was almost immediately pushed out by the thesis and the term paper, which seemed more relevant to departments' needs. In 1899, the Harvard forensic system was replaced by remedial composition studies, a pattern that was repeated at most US research universities and continues to be repeated elsewhere, and represents the ongoing tension between enrichment and remediation.

The Harvard forensic 'theme' was structured like an oration, as are our academic essays. It took the form prescribed for a controversia, which was a forensic debate based on an imaginary legal case that was the most advanced declamatio ('declaration'), or practice exercise for students of rhetoric in Rome. The declamatio was modelled on a Greek progymnasmata ('preliminary exercise') for orators and immortalised by Seneca (1974). ${ }^{9}$ It had to contain an introduction (exordium), statement of the facts (narratio), proofs and refutations (confirmation and refutatio), and a conclusion (peroratio) - which fits neatly into our intuitive three-act narrative arc. It sometimes even included a summary (prepositio) and/or outline of the argument (partitio) after the exordium and narratio, very much like the thesis statement and outline that have become conventional at the end of the introduction in academic 
writing. The student could be asked to make a case for or against an issue, or both.

Table 2. The structure of progymnasmata, controversiae and the academic essay (De Brauw 2007)

\begin{tabular}{|l|l|l|l|}
\hline Progymnasmaton & Controversia & Function & The essay \\
\hline prooimion ('prelude') & exordium & introduction & \multirow{2}{*}{ introduction } \\
\hline diegesis ('narration') & narratio & statement of facts & \\
\hline & [prepositio, partitio & summary, outline of argument] & \\
\hline pistis ('persuasion') & confirmatio & proof & \multirow{2}{*}{ body } \\
\hline & refutatio & refutation & conclusion \\
\hline epilogos ('conclusion') & peroratio & conclusion & \multicolumn{2}{|l}{} \\
\hline
\end{tabular}

Thus, if forensic rhetoric gives us the nature of academic argument, the forensic debate based on forensic rhetoric (the disputatio) gives us the shape of the academic essay, providing the elements of the point-first essay that is the model for most academic writing:

- the introduction (exordium), which provides context (narratio), ending with

o a summary of the argument (prepositio), namely, the thesis, or point

0 an outline of the argument (partitio), namely, its structure

- the body, addressing 'both sides' of the argument (confirmation and refutatio)

- the conclusion (peroratio).

Its motto is 'tell me what you're going to tell me, tell me, and then tell me what you told me'. This model of the essay - often called the 'five-paragraph essay' (Schaffner 2003) ${ }^{10}$ - has thrived because it is efficient and aims to inform its reader. It is up-front with its point, which is what most time-poor academics read for, after all. And it allows writers to show what they know and to emphasize their point, or thesis (Greek 'position'), at the expense of others'. As such, it offers an easily examinable model and, because it is entirely generic, an easily teachable model, providing a common lexicon for teachers and students to talk about writing. But it treats writing as an apolitical instrument.

\section{'Forensis'}

The form of analysis that Eyal Weizman calls forensis can enable us to bring to light the politics of the academic essay - and marks a not-so-sudden peripeteia in my story of academic writing. In Forensic Architecture (2014), he argues that forensis aims to 'reorient the practice of contemporary forensics and expand it' (9). As he puts it, 'rather than being limited to presentation in the legal domain alone, forensis seeks to perform across a multiplicity of forums, political and juridical, institutional and informal' (9). He argues that, over time, the ambit of forensics has shrunk: from the forum ('public 
place'), to the court of law, to the use of science and medicine in the court of law. ${ }^{11} \mathrm{He}$ wants to reverse that process in order to reclaim forensis as a 'critical practice' (Weizman 2014), one that allows not only people, but also things, to present their 'arguments' in public, as happens when forensic evidence 'speaks' through the lawyer to the circumstances of a crime in a court of law (Weizman 2012: 8-9).

Nonetheless, forensis does take its cue from forensic science:12 '[it] is used to interrogate the relation between the two constitutive sites of forensics - namely fields and forums', the field being 'the site of investigation' and the forum, 'the place where the results of an investigation are presented and contested' (Weizman 2014: 9). But a field is 'not only a neutral, abstract grid on which traces of a crime can be plotted out, but itself a dynamic and elastic territory, a force field that is shaped by but also shapes conflict' (Weizman 2014: 9). Weizman gives the example of the 'pyramids of Gaza', three-story residential buildings in the Gaza Strip that have been partially demolished by armoured bulldozer and collapse into a rough pyramid - clearly, a conflictual field (2012: 4-5). A forum involves 'a shifting triangulation between three elements: a contested object or site, an interpreter tasked with translating "the language of things" [through prosopopoeia, or personification], and the assembly of a public gathering' (Weizman 2014: 9). Because of new forensic technologies, a forum need not be a given space; it can be virtual - and the interpreter need not be a person; it can be transmedial. Thus, in the case of the pyramids of Gaza, evidence comes not only from on-site photography, but also from satellite imagery.

In this essay, I have taken the academic essay as my object, or 'field', and the university as its forum. What more can the academic essay tell us about the 'crime' of academic writing? So far, the nexus of forensic rhetoric and academic writing has revealed how the field of the academic essay is marked by its kinship with what Pierre Bourdieu calls the larger 'juridical field', the field of the law. In 'The Force of Law: Toward a Sociology of the Juridical Field', Bourdieu analyses the structure (distribution, or principles of 'vision and division' [1986: 852]) and practices (habitus) of that field. Several features of his analysis corroborate my characterisation of academic writing (see Table 2).

Firstly, the juridical field solves the problem of 'competition for monopoly of the right to determine the law' by 'establishing a social division between lay people and professionals' based on their capacity to make legal judgments (Bourdieu 1986: 817) that makes lawyers' communis opinio doctorum (professional common knowledge) appear 'transcendental', or objective (Bourdieu 1986: 819). The same is true of academic writing, the social division between students and academics, and academics' (apparent) expertise in academic writing. Secondly, it is marked by a 'rhetoric of impersonality and of neutrality' (Bourdieu 1986: 819) that produces a 'neutralization effect' and a 'universalisation effect' (Bourdieu 1986: 820). The former, it creates through passive and impersonal syntax; the latter, through a number of procedures: expressing norms in the indicative (as statements of fact); employing constative verbs to emphasize the 'factual' (to make statements that can be judged true or false); presupposing 'an ethical consensus'; and having 'recourse to fixed formulas and locutions' (Bourdieu 1986: 820). These effects imply that judgements are 'based upon rigorous deduction from a body of internally coherent rules' (Bourdieu 1986: 820). The 
same is true to varying degrees of academic writing and its 'rules' in many disciplines. Thirdly, it establishes a 'contract defining entry into the juridical field' that has three requirements: to 'come to a decision'; to 'conform to ... recognized procedural categories established in the history of the law'; and to '[refer] to and [conform] with precedent' (Bourdieu 1986: 832). The same is true of the requirement for academic writing to make a case for or against something; to argue through demonstration via evidence, induction and deduction; and to cite authorities' arguments as precedents.

What Bourdieu's analysis of the juridical field reveals is that all fields, including academic writing, exercise their power 'only through the complicity' - or illusio, to use Bourdieu's term - 'of those who are dominated by it' (Bourdieu 1986: 844). For this reason, most academic writers, be they students being assessed or academics being peer-reviewed, cannot but be complicit in 'confirm[ing] the established order' of the field's structure and practices: they 'achieve their power of creative utterance to the extent, and only to the extent, that they propose principles of vision and division objectively adapted to the pre-existing divisions of which they are the products' (Bourdieu 1986: 839). Both the law and academic writing promote the 'naturalization', and, more fundamentally, the 'ontological glorification' of their respective fields (Bourdieu 1986: 840, 846). The academic essay is thus conditioned by its field in particular ways that delimit what we can think through it.

To the characteristic social division, rhetoric and contract of the field of academic writing, I would add a feature that supplements Bourdieu's analysis: a characteristic 'chronotope', or coherent spatiotemporal structure (Bakhtin 1981: 84). Like many other aspects of today's academosphere, the point-first essay that is the model for most academic writing is 'econometric': it involves a closed economy (from the Greek oikos, 'management'), for example, a learning activity or space, that can be predictably measured (from the Greek metron, 'measure') according to predetermined learning outcomes. It thus occupies a future perfect ('will have been') world of 'closed loops' because it works backwards from a predetermined outcome ('o') - its thesis, or point to construct its arguments, as the diagram in figure 2 suggests.

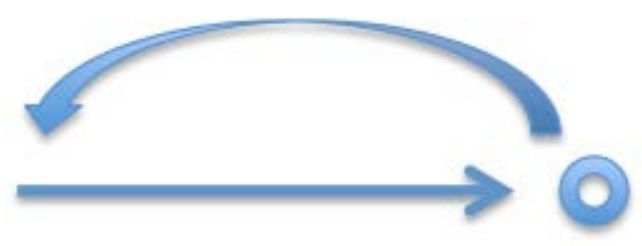

Figure 2. The point-first essay in hindsight.

(In this, the point-first essay is structured not unlike Biggs's [1996] 'constructive alignment' - or 'backward design' [Wiggins and McTighe 1998] - model that dominates curriculum design today, which aligns the assessment tasks that measure learning activities to learning outcomes.) Such closed loops are favoured by corporate 
'total quality management' because they enable the predictable cost accounting of inputs and outputs - but they don't translate well to much academic work, including teaching and writing. We teachers must bear in mind that requiring students (or academics, indeed, through peer review) to construct a model point-first essay to demonstrate their socialisation into the field of academic writing is also training them to be good 'econometricians'.

What is the point of my enabling the academic essay to 'speak' in this way? It reveals how, because the academy has embraced the contractualism that characterises neoliberalism, the academosphere today has become risk-averse (see Biesta 2014) - as the law has always been. Olssen and Peters define contractualism - for students or academics and the university (and the university and other corporates) - as 'based upon measurable outputs' (see Matheson 1997):

In neoliberalism the patterning of power is established on contract, which in turn is premised upon a need for compliance, monitoring, and accountability organized in a management line [of principal and agent relationships] and established through a purchase contract. (Olssen and Peters 2005: 325)

The academic essay too is risk-averse in the constant second-guessing that is demanded of the writer in a contractual academosphere where the reader/consumer whom they hope to persuade is positioned as an assessor or peer reviewer (albeit, increasingly, one who dare not fail the writer). To counter this contractualism, it needs to risk the 'encounter between human beings' that is the mark of education worthy of the name (Biesta 2014: 1) - and of writing.

\section{A new forum}

Gert Biesta (2014: 2) argues that it is wrong to want education to be 'strong, secure, predictable and risk-free' - as econometric 'education' aims to be. It is 'the weakness of education - the fact that there can never be a perfect match between educational “input” and "output” - ... that makes education possible' (Biesta 2014: 3-4). ${ }^{13}$ This is because education works 'by establishing opportunities for dialogue with what or who is other', through 'weak connections of communication and interpretation, of interruption and response’ (Biesta 2014: 3, 4). Writing works similarly. I would argue that we need to weaken academic writing by rethinking its relation to its audience in terms of Michael Warner's (2008) concepts of textual 'publics' and 'counterpublics'. According to Warner, textual publics are not merely audiences; they are social imaginaries that define those who address and belong to them, and what they can do and say - not unlike Bourdieu's fields:

To address a public or to think of oneself as belonging to a public is to be a certain sort of person, to inhabit a certain kind of social world, to have at one's disposal certain media and genres, to be motivated by a certain normative horizon, and to speak within a certain language ideology. (2008: 10)

In contrast, textual counterpublics 'are defined by their tension with a larger public', by their 'conflict with [its] norms and contexts' (Warner 2008: 56, 63). What I would call 'weak academic writing' addresses a public that runs counter to that addressed by its 
stronger cousin. Whereas the model of the strong academic essay is the point-first essay, that of the weak academic essay is the 'point-last' essay (Williams 1981). The pointlast essay exemplifies three 'risky' characteristics of counterpublics: like them, it does 'transformative and creative work'; it is 'orientated to the poetic-expressive dimensions of language'; and it 'risk[s] estrangement' from its audience (Warner 2008: 62, 116, 122).

How so? The point-last essay can perform its argument variously: its content can be allowed to shape its form, and vice versa. (Two different arguments are two different essays, and two different essays are two different arguments.) It can express possibilities, even counterfactual or fictive ones, by working through a range of points or working toward a point. Figure 3 represents these two options (the former, on the left; the latter, on the right), as seen in hindsight; hence, the 'winning' path to what seemed like an unknown outcome (x) ahead of time is solid, and the others, dashed. In fact, its chronotope could well be a wander through the forum in search of what we will only know when we find it.
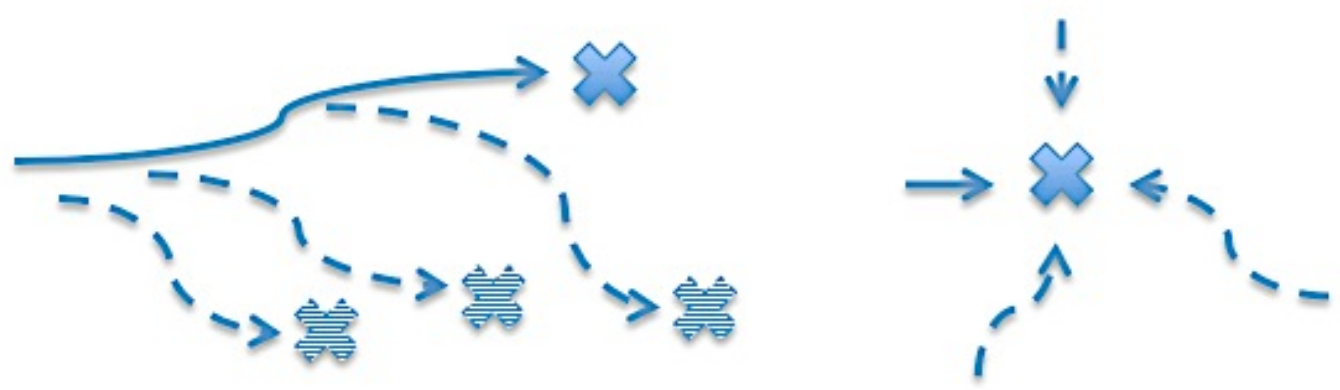

Figure 3. The point-last essay in hindsight

Unlike the point-first essay, which is monological and aims to inform its reader (persuasively, of course), the point-last essay is dialogical and aims to interact with its reader through the medium of form. Paul Heilker's The Essay: Theory and Pedagogy for an Active Form, the best vade mecum of the point-last essay, almost gets it right: 'In the art of the essay, we write in a perpetual movement toward knowledge and wisdom; in reading essays, we witness writers perpetually moving toward wisdom and understanding' (1996: 183). I would add: '. . . and, as readers, we perpetually move toward knowledge and understanding'. It is defined by its quest for a form that will activate the content for readers, ${ }^{14}$ or rather, that will open a dialogue with them. Of course, except perhaps in a 'live' reading or an online forum, it is not a true dialogue (from the Greek dialogos, 'conversation'); rather, it is an injunction to essay (from the Old French essai, 'trial, attempt, essay'). ${ }^{15}$ According to Heilker (1996: 169), the form of the point-last essay is 'not the form of a thing, but rather the form of an activity or action': it is really essaying, trying out a way of thinking. As such, it is often, as Warner suggests, 'orientated to the poetic-expressive dimensions of language' (2008: 116).

My story too ends with an injunction. Taking risks to transform the essay, and academic writing more generally, can have transformative political effects; in fact, it can 'create 
rival publics, even rival modes of publicness' (Warner 2008: 14; see Culler and Lamb 2003). Doing so can problematize the field and form of academic writing to generate a weak counterpublic 'oriented to strangeness, risk and worldmaking in a scene of concretely mediated but open-ended exchange' (Warner 2008: 158, after Foucault $2000 \mathrm{~b}$ ). Of course, that risks estranging our audience, but more of us need to take that risk, to choose not to follow the 'path of obedient submission to the academic world' (Joeres and Mittman 1993: 20). As the greatest essayist, Michel de Montaigne, writes: 'Nothing noble is achieved without risk' (2003: 145).

\section{Endnotes}

1. Compare Braidotti (2013) on the 'forensic turn', a reading of contemporary social and cultural theory as 'haunted by the spectre of extinction and by the limitations of the project of western modernity' (121).

2. 'Effective persuasive writers do more than make well-supported claims ("I say”); they also map those claims relative to the claims of others (“they say”)' (Graff \& Birkenstein 2014: xix).

3. In formalising forensic rhetoric, Aristotle was drawing on a long tradition of treatments of the topic, which dominated prior rhetorical handbooks and which he summarised in the lost Synagoggē Technōn (Cooper 2007: 203-204).

4. For the false objectivity of the positivistic 'bad essay', see Adorno (1984: 153-154).

5. Aristotle seems to have taken this idea from Plato, or rather his persona Socrates, in the Phaedrus (Plato 2002; see 267a-b, 272d-273b).

6. Toulmin's (2003) innovation was to explore the nature of the 'laws' - often just assumptions or generalisations - that we use to 'warrant' our informal arguments, that is, to link grounds (minor premises) and claims (conclusions).

7. Genealogical critique exemplifies what has been called the 'hermeneutics of suspicion' (Ricoeur 1970), 'a distinctively modern style of interpretation that circumvents obvious or self-evident meanings in order to draw out less visible and less flattering truths' (Felski 2012).

8. Through his hugely influential introduction to academic writing, The Principles of Rhetoric and Their Application (1878), Hill inaugurated what is now known as Current Traditionalist rhetoric, with his focus on correct grammar and plain style in the service of exposition (he devotes the whole first half of the book to word choice). The section on 'Argumentative Composition' (184-248) relies heavily on Aristotle on forensic rhetoric.

9. The controversia was based on two progymnasmata, or preliminary rhetorical exercises for adolescent students of rhetoric: the kataskeue ('confirmation') and anaskeve ('refutation'). However, the topics of the Greek exercises were mythical, not forensic (Kennedy 1994).

10. For the reductio ad absurdum of academic writing templates, see Schaffer (1995) on the 'fivesentence paragraph', constructed similarly to the five-paragraph essay.

11. Forensis is the adjective of forum, 'marketplace, open space, public place' (like the Greek agora), akin to foris, 'out of doors'. It meant 'of or pertaining to the market or forum, public' (Lewis and Short 1879: 773-774). It is the root of the English word 'forensic', coined in the seventeenth century to mean 'pertaining to or suitable for courts of law' (Harper 2016). (Weizman takes it to be a noun, by analogy with Greek nouns ending in 'is' like analysis or hypothesis.) Interestingly, 'court', ultimately from the Latin cors/cohors 'enclosed yard' (hence, 'cohort'), is etymologically synonymous with forum (Harper 2016).

12. For an alternative to forensis, see Greetham's 'textual forensics' (1996), a hybrid of the forensic sciences and textual studies that borrows the discourse of forensic science, namely, evidence and witnesses 'to take up questions related to the scientific method in bibliography and textual criticism, internal vs. external evidentiary states, and the conditions of bibliographical knowledge' (Kirschenbaum 
2014: 57). Note that, in Mechanisms: New Media and the Forensic Imagination (2008), Kirschenbaum applies Greetham's 'textual forensics' to digital materials.

13. For 'weak thought' as a species of postmetaphysics, see Vattimo (2012).

14. For a range of practical strategies to activate the essay, see Sturm (2012: 16).

15. Interestingly, the verb 'essay', meaning 'to put to proof, test the mettle of', from the Old French essai, 'trial, attempt, essay', ultimately derives from the Latin exigere 'drive out; require, exact; examine, try, test' (Harper 2016). Not for nothing was the sigil of Michel de Montaigne a pair of scales with the motto 'Que sçay-je?', that is, 'What do I know?'

\section{Works cited}

Adorno, TW 1984 ‘The essay as form’, New German critique 32 (Spring-Summer): 151-71

Aristotle 1902 The poetics of Aristotle, SH Butcher (trans), MacMillan, London

- 1991 The art of rhetoric, HC Lawson-Tancred (trans), Penguin, Harmondsworth

Bakhtin, MM 1981 The dialogic imagination: four essays, C Emerson and M Holquist (trans), University of Texas Press, Austin

Bers, Victor 2009 Genos dikanikon: amateur and professional speech in the courtrooms of classical Athens, Washington, DC: Center for Hellenic Studies: http://nrs.harvard.edu/urn-

3:hul.ebook:CHS_Bers.Genos_Dikanikon.2009 (accessed 3 March 2017)

Biesta, GJJ 2014 The beautiful risk of education, Paradigm, Boulder

Biggs, J 1996 'Enhancing teaching through constructive alignment', Higher education 32, 3 (October): 347-364

Booth, WC 1963 'The rhetorical stance', College composition and communication 14, 3 (October): $139-145$

Bourdieu, P 1986 'The force of law: toward a sociology of the juridical field', Hastings law journal 38, 5 (July): 805-853

Braidotti, R 2013 The posthuman, Malden: Polity, Cambridge

Cicero 1976 De inventione; topica, HM Hubbel (trans), Harvard University Press, Cambridge

[Cicero] 1968 Rhetorica ad herennium, H Caplan (trans), Harvard University Press, Cambridge

Clark, W 2008 Academic charisma and the origins of the research university, University of Chicago Press, Chicago

Cooper, C 'Forensic oratory' in I Worthington (ed) A companion to Greek rhetoric, Blackwell, Oxford: 203-219

Culler, JD and K Lamb 2003 Just being difficult?: academic writing in the public arena, Stanford University Press, Stanford

De Brauw, M 2007 'The parts of the speech’ in I Worthington (ed) A companion to Greek rhetoric, Blackwell, Oxford: 187-202

Felski, R 2012 ‘Critique and the hermeneutics of suspicion’, M/C journal 15, 1 (March): np

Foucault, M 2000a 'Nietzsche, genealogy, history', Essential works of Foucault 1954-1984, vol. 2: aesthetics, method and epistemology, J Faubian (ed), Penguin, New York: 369-391

— 2000b 'Polemics, politics and problematizations: an interview with Michel Foucault', Essential works of Foucault 1954-84, vol. 1: ethics: subjectivity and truth, P Rabinow (ed), Penguin, New York: $111-119$

Garver, E 1994 Aristotle’s rhetoric: an art of character, University of Chicago Press, Chicago 
Graff, G and C Birkenstein 2014 They say, I say: the moves that matter in academic writing (third ed), WW Norton, New York

Greetham, DC 1996 ‘Textual forensics’, PMLA 111, 1 (January): 32-51

Harper, Douglas 2016 Online etymology dictionary: http://www.etymonline.com (accessed 3 March 2017)

Heilker, P 1996 The essay: theory and pedagogy for an active form, National Council of Teachers of English, Urbana

Hesk, J 2009 'Types of oratory’ in E Gunderson (ed) The Cambridge companion to ancient rhetoric, Cambridge University Press, Cambridge: 145-161

Hill, AS 1878 The principles of rhetoric and their application, Harper and Row, New York Joeres, R-E and E Mittman 1993 ‘An introductory essay’ in R-E Joeres and E Mittman (eds) The politics of the essay: feminist perspectives, Indiana University Press, Bloomington: 12-20

Kennedy, GA 1994 A new history of classical rhetoric, Princeton University Press, Princeton Kinneavy, JL 1971 A theory of discourse: the aims of discourse, Prentice-Hall, Englewood Cliffs Kirschenbaum, M 2014 .Txtual [sic] forensics, Textual cultures: texts, contexts, interpretation 9, 1 (Winter): 55-64

— 2008 Mechanisms: new media and the forensic imagination, MIT Press, Cambridge

Lea, M and BV Street 1998 'Student writing in higher education: an academic literacies approach', Studies in higher education 23, 2 (January): 157-172

Lewis, CT and C Short 1879 A Latin dictionary, Clarendon Press, Oxford

McLean, C and K Hoskin 1998 'Organizing madness: reflections on the forms of the form', Organization 5, 4 (November): 519-541

Mangum, GC and ABA Mangum 1983 'Forensic rhetoric and invention: composition students as attorneys', College composition and communication 34, 1 (February): 43-56

Matheson, A 1997 'The impact of contracts on public management in New Zealand' in G Davis, B Sullivan and A Yeatman (eds) The new contractualism?, Macmillan, Melbourne: 164-179

Montaigne, M de 2003 The complete essays, MA Screech (trans), Penguin, London

Murphy, JJ 1974 Rhetoric in the Middle Ages: a history of rhetorical theory from Saint Augustine to the Renaissance, University of California Press, Berkeley

Olssen, M and MA Peters 2005 'Neoliberalism, higher education and the knowledge economy: from the free market to knowledge capitalism', Journal of Education Policy 20, 3 (May): 313-345

Plato 2002 Phaedrus, R Waterfield (trans), Oxford University Press, Oxford

Ricoeur, P 1970 Freud and philosophy: an essay on interpretation, Yale UP, New Haven

Rorty, A 1996 'Structuring rhetoric' in A Rorty (ed) Essays on Aristotle's rhetoric, University of California Press, Berkeley: 1-33

Russell, DR 2002 Writing in the academic disciplines: a curricular history (second ed), Southern Illinois University Press, Carbondale

Schaffner, S 2003 'The five-paragraph essay: friend or foe?' in S Dobrin and A Bawarshi (eds) A Closer Look: The Writer's Reader, McGraw Hill, New York

Seneca the Elder 1974 Declamations, vols 1-2, Controversiae, M Winterbottom (ed), Harvard University Press, Cambridge

Schaffer, JC 1995 Teaching the multiparagraph essay: a sequential nine-week unit (third ed), Jane Schaffer Publications, San Diego

Sturm, Sean 2012 'Terra (in)cognita: mapping academic writing', TEXT: journal of writing and writing courses 16, 2 (October): http://www.textjournal.com.au/oct12/sturm.htm (accessed 3 March 2017) 
Sturm, S and S Turner 2011 “"Built pedagogy”: the University of Auckland Business School as Crystal Palace', Interstices 12: 23-25

Swales, J 1990 Genre analysis: English in academic and research settings, Cambridge University Press, Cambridge

Thomas, F-N and M Turner 2011 Clear and simple as the truth: writing classic prose, Princeton University Press, Princeton

Toulmin, S 2003 The uses of argument: updated edition, Cambridge University Press, Cambridge Vattimo, G 2012 'Dialectics, difference, weak thought' in G Vattimo and PA Rovatti (eds) Weak thought, SUNY Press, Albany: 39-52

Vogler, C 2007 The writer's journey: mythic structure for writers (third ed), M. Wiese Productions, Studio City

Weizman, E 2014 'Introduction: forensis', Forensis: the architecture of public truth, Sternberg, Berlin: 9-32

— 2012 Forensic architecture: notes from fields and forums, Hatje Cantz, Berlin

Wiggins, G and J McTighe 1998 Understanding by design, Merrill Prentice Hall, Upper Saddle River

Williams J 1981 Style: toward clarity and grace, University of Chicago Press, Chicago 